\title{
Trend of atmospheric mercury concentrations at Cape Point for 1995-2004 and since 2007
}

\author{
Lynwill G. Martin ${ }^{1}$, Casper Labuschagne ${ }^{1}$, Ernst-Günther Brunke ${ }^{1}$, Andreas Weigelt ${ }^{2, a}$, Ralf Ebinghaus ${ }^{2}$, and \\ Franz Slemr ${ }^{3}$ \\ ${ }^{1}$ South African Weather Service c/o CSIR, P.O. Box 320, Stellenbosch 7599, South Africa \\ ${ }^{2}$ Helmholtz-Zentrum Geesthacht (HZG), Institute of Coastal Research, Max-Planck-Strasse 1, 21502 Geesthacht, Germany \\ ${ }^{3}$ Max Planck Institute for Chemistry, Hahn-Meitner-Weg 1, 55128 Mainz, Germany \\ a now at: Federal Maritime and Hydrographic Agency (BSH), 22589 Hamburg, Germany
}

Correspondence to: Lynwill G. Martin (lynwill.martin@weathersa.co.za) and Franz Slemr (franz.slemr@mpic.de)

Received: 12 October 2016 - Discussion started: 24 October 2016

Revised: 23 January 2017 - Accepted: 25 January 2017 - Published: 15 February 2017

\begin{abstract}
Long-term measurements of gaseous elemental mercury (GEM) concentrations at Cape Point, South Africa, reveal a downward trend between September 1995 and December 2005 and an upward one from March 2007 until June 2015, implying a change in trend sign between 2004 and 2007. The trend change is qualitatively consistent with the trend changes in GEM concentrations observed at Mace Head, Ireland, and in mercury wet deposition over North America, suggesting a change in worldwide mercury emissions.

Seasonally resolved trends suggest a modulation of the overall trend by regional processes. The trends in absolute terms (downward in 1995-2004 and upward in 2007-2015) are highest in austral spring (SON), coinciding with the peak in emissions from biomass burning in South America and southern Africa. The influence of trends in biomass burning is further supported by a biennial variation in GEM concentration found here and an El Niño-Southern Oscillation (ENSO) signature in GEM concentrations reported recently.
\end{abstract}

\section{Introduction}

Mercury and especially methyl mercury which bioaccumulates in the aquatic nutritional chain are harmful to humans and animals (e.g., Mergler et al., 2007; Scheuhammer et al., 2007; Selin, 2009; and references therein). Mercury, released into the environment by natural processes and by anthropogenic activities, cycles between the atmosphere, water, and land reservoirs (Selin et al., 2008). In the atmosphere, mercury occurs mostly as gaseous elemental mercury (GEM), which with an atmospheric lifetime of $0.5-$ 1 year can be transported over large distances (Lindberg et al., 2007). Mercury is thus a pollutant of global importance and as such on the priority list of several international agreements and conventions dealing with environmental protection and human health, including the United Nations Environment Programme (UNEP) Minamata Convention on Mercury (www.mercuryconvention.org).

Because of fast mixing processes in the atmosphere, monitoring of tropospheric mercury concentrations and of its deposition will thus be the most straightforward way to verify the decrease of mercury emissions expected from the implementation of the Minamata Convention. Regular monitoring of atmospheric mercury started in the mid-1990s with the establishment of mercury monitoring networks in North America (Temme et al., 2007; Prestbo and Gay, 2009; Gay et al., 2013). Until 2010 only a few long-term mercury observations had been reported from other regions of the Northern Hemisphere and hardly any from the Southern Hemisphere (Sprovieri et al., 2010). The Global Mercury Observation System (GMOS, www.gmos.eu) was established in 2010 to extend the mercury monitoring network, especially in the Southern Hemisphere (Sprovieri et al., 2016).

Decreasing atmospheric mercury concentrations and wet mercury deposition have been reported for most sites in the Northern Hemisphere (Temme et al., 2007; Prestbo and Gay, 2009; Ebinghaus et al., 2011; Gay et al., 2013). At Cape 
Point, the only site in the Southern Hemisphere with a longterm record exceeding a decade, decreasing mercury concentrations were also observed between 1996 and 2004 (Slemr et al., 2008). The worldwide decreasing trend has been at odds with increasing mercury emissions in most inventories (Muntean et al., 2014, and references therein). Soerensen et al. (2012) thought that decreasing mercury concentrations in seawater of the North Atlantic were responsible for the decrease, at least in the Northern Hemisphere. The most recent inventories, however, attribute the decrease of atmospheric mercury concentrations to a decrease in mercury emissions since 1990 (Zhang et al., 2016). The decrease in mercury emissions was attributed to the decrease of emissions from commercial products, to changing speciation of emission from coal-fired power plants, and to the improved estimate of mercury emissions from artisanal mining. According to Zhang et al. (2016) worldwide anthropogenic emissions decreased from $2890 \mathrm{Mg}$ year $^{-1}$ in 1990 to $2160 \mathrm{Mg}$ year $^{-1}$ in 2000 and increased slightly to $2280 \mathrm{Mg}$ year $^{-1}$ in 2010.

In the first approximation, the observed trends in atmospheric mercury should follow these changes. There is indeed some recent evidence that the downward trend in the Northern Hemisphere is slowing or even turning upwards (Weigelt et al., 2015; Weiss-Penzias et al., 2016). Here we report and analyze the trends of atmospheric mercury concentrations at the Global Atmospheric Watch (GAW) station Cape Point between 1995 and 2004 and from March 2007 until June 2015.

\section{Experimental}

The Cape Point site $\left(\mathrm{CPT}, 34^{\circ} 21^{\prime} \mathrm{S}, 18^{\circ} 29^{\prime} \mathrm{E}\right)$ is operated as one of the GAW baseline monitoring observatories of the World Meteorological Organization (WMO). The station is located on the southern tip of the Cape Peninsula within the Cape Point National Park on top of a peak $230 \mathrm{~m}$ above sea level and about $60 \mathrm{~km}$ south from Cape Town. The station has been in operation since the end of the 1970s, and its current continuous measurement portfolio includes $\mathrm{Hg}, \mathrm{CO}, \mathrm{O}_{3}, \mathrm{CH}_{4}, \mathrm{~N}_{2} \mathrm{O},{ }^{222} \mathrm{Rn}$, and $\mathrm{CO}_{2}$, as well as several halocarbons, particles, and meteorological parameters. The station receives clean marine air masses for most of the time. Occasional events with continental and polluted air can easily be filtered out using a combination of $\mathrm{CO}$ and ${ }^{222} \mathrm{Rn}$ measurements (Brunke et al., 2004). Based on the ${ }^{222} \mathrm{Rn} \leq 250 \mathrm{mBq} \mathrm{m}^{-3}$ criterion about $35 \%$ of the data are classified annually as baseline.

Gaseous elemental mercury (GEM) was measured by a manual amalgamation technique (Slemr et al., 2008) between September 1995 and December 2004 and by the automated Tekran 2537B instrument (Tekran Inc., Toronto, Canada) beginning March 2007. Typically, $\sim 13$ measurements per month were made using the manual technique, each covering $3 \mathrm{~h}$ sampling time. The manual technique was compared with the Tekran technique in an international intercomparison (Ebinghaus et al., 1999) and provided comparable results.

Beginning March 2007 GEM was measured using an automated dual-channel, single-amalgamation, cold-vapor atomic fluorescence analyzer (Tekran Model 2537A or B analyzer, Tekran Inc., Toronto, Canada). The instrument utilized two gold cartridges. While one is adsorbing mercury during a sampling period, the other is being thermally desorbed using argon as a carrier gas. Mercury is detected using cold-vapor atomic fluorescence spectroscopy (CVAFS). The functions of the cartridges are then interchanged, allowing continuous sampling of the incoming air stream. Operation and calibration of the instruments follow established and standardized procedures of the GMOS (www.gmos.eu) project. The instrument was run with 15 min sampling frequency, while $30 \mathrm{~min}$ averages were used for the data analysis. All mercury concentrations reported here are given in units of nanogram per square meter $\left(\mathrm{ng} \mathrm{m}^{-3}\right)$ at $273.14 \mathrm{~K}$ and $1013 \mathrm{hPa}$.

The Mann-Kendal test for trend detection and an estimate of Sen's slope were made using the program by Salmi et al. (2002).

\section{Results and discussion}

The upper panel of Fig. 1 shows monthly average GEM concentrations calculated from all data from March 2007 until June 2015, and in the lower panel monthly average GEM concentrations were calculated from baseline data, i.e., GEM concentrations measured at ${ }^{222} \mathrm{Rn}$ concentration $\leq 250 \mathrm{mBq} \mathrm{m}^{-3}$. The slope of the least-squares fit of all data $\left(0.0222 \pm 0.0032 \mathrm{ng} \mathrm{m}^{-3}\right.$ year $\left.^{-1}\right)$ is not significantly different from the slope calculated from the baseline data only $\left(0.0219 \pm 0.0032 \mathrm{ng} \mathrm{m}^{-3}\right.$ year $\left.^{-1}\right)$. Sen's slope and trend significance for all $\left(0.0210 \mathrm{ng} \mathrm{m}^{-3}\right.$ year $\left.^{-1}\right)$ and baseline $\left(0.0208 \mathrm{ng} \mathrm{m}^{-3}\right.$ year $\left.^{-1}\right)$ data are listed in Table 1 . Sen's slopes tend to be somewhat lower than the slopes from the least-squares fits, but they are in agreement within their $95 \%$ uncertainty range. All trends are highly significant, i.e., at a level $\geq 99.9 \%$. The results are essentially the same whether monthly median or monthly average concentrations are used. This shows that the trend is robust and not influenced by occasional pollution or depletion events (Brunke et al., 2010, 2012).

For comparison we also calculated the trends for the manually measured GEM concentrations during the period September 1995-December 2004. These data have an annual coverage of only about $300 \mathrm{~h}$ per year, i.e., about $3 \%$ in contrast to the Tekran measurements from 2007 onward, for which the coverage was nearly $100 \%$. Baseline data were not filtered out from this data set because (a) on average only 13 measurements were available per month and (b) ${ }^{222} \mathrm{Rn}$ was measured only since March 1999 and thus cannot be used as 

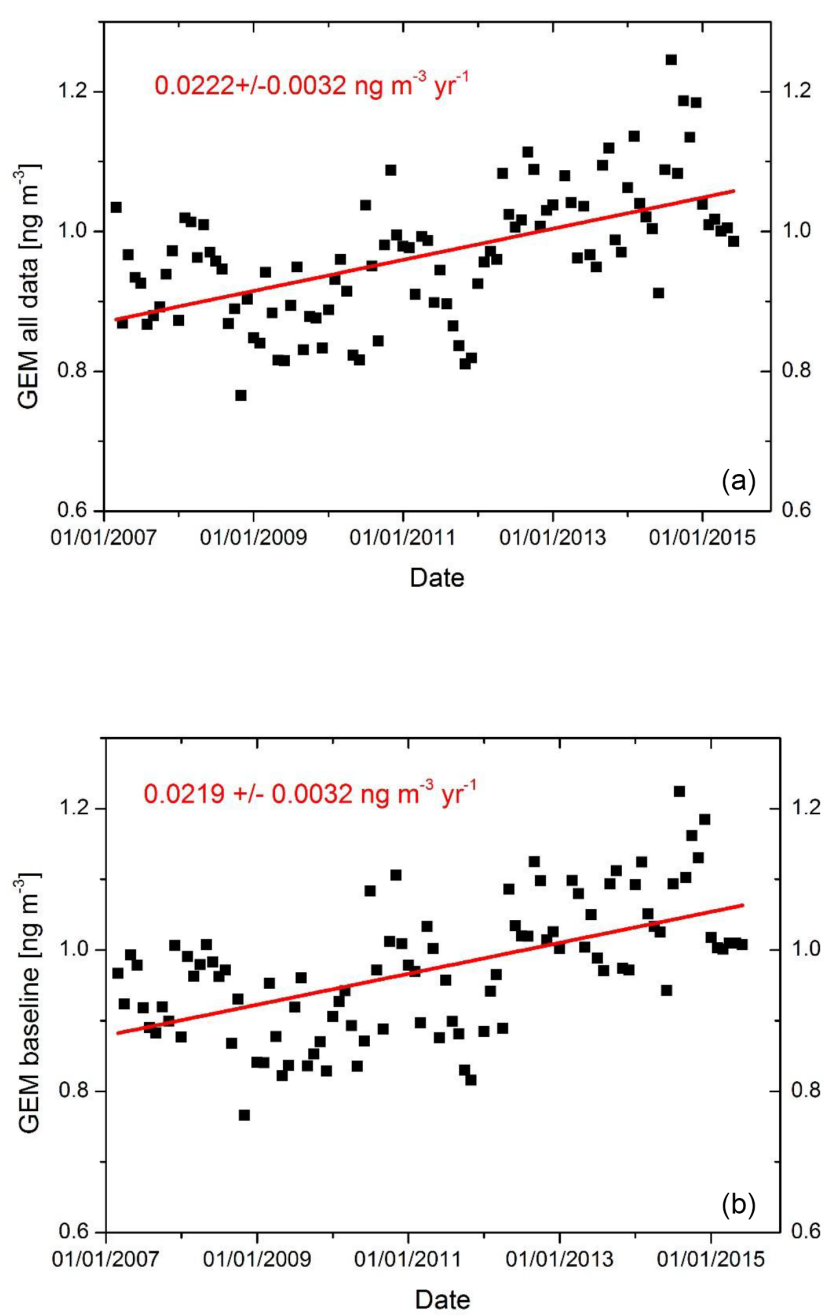

Figure 1. Monthly average GEM concentrations and their leastsquares fit: upper panel - all data; lower panel - baseline data (i.e., only GEM concentrations at ${ }^{222} \mathrm{Rn}$ concentrations $\leq 250 \mathrm{mBq} \mathrm{m}^{-3}$.

a criterion for the whole period. In Table 2 we list the trends calculated from the least-squares fit of the monthly medians. Monthly averages provide qualitatively the same trends with lower significance, because of their larger sensitivity to extreme GEM concentrations. The trend of all monthly medians of $-0.0176 \pm 0.0027 \mathrm{ng} \mathrm{m}^{-3}$ year $^{-1}$ is somewhat higher than $-0.015 \pm 0.003 \mathrm{ng} \mathrm{m}^{-3}$ year $^{-1}$ (Slemr et al., 2008) calculated from the 1996 and 1999-2004 annual averages but is within the uncertainty of both calculations.

The upward trend after March 2007 and the downward trend between 1995 and 2004 were measured by different techniques: the former one with a Tekran instrument and the latter one using the manual technique. For reasons outside of our control we could not operate both techniques side by side for a reasonable length of time. Although the measurements by both techniques agreed well during an international field intercomparison (Ebinghaus et al., 1999), we do not claim here that they are comparable without an extended intercomparison of both techniques at Cape Point. Assuming internal consistency of each of the data sets, it is, however, obvious that the decreasing trend between 1995 and 2004 turned to an increasing one from 2007 onward, implying that the turning point was located between 2004 and 2007.

The trend reversal at Cape Point is the most pronounced but not the only evidence that the hemispheric trends in mercury concentrations are changing. An analysis of 1996-2013 data from Mace Head, classified according to the geographical origin of the air masses, showed (a) that the downward trend of mercury concentration in air masses originating from over the Atlantic Ocean south of $28^{\circ} \mathrm{N}$ is substantially lower than for all other classes originating north of $28^{\circ} \mathrm{N}$ and (b) that all downward trends for air masses originating from north of $28^{\circ} \mathrm{N}$ are decelerating (Weigelt et al., 2015). The apparent inconsistency that no decelerating trend for air masses from south of $28^{\circ} \mathrm{N}$ was found can be explained by the fact that the changes of a smaller trend are likely to be more difficult to detect. Weiss-Penzias et al. (2016) recently reported that the wet mercury deposition was decreasing at $53 \%$ of the sites in the US and Canada and was increasing at none of the sites over the period 1997-2013. Over the period 2008-2013, however, the mercury wet deposition was decreasing only at $6 \%$ of the sites but was increasing at $30 \%$ of the sites. Thus the sign change of the trend at Cape Point somewhere between 2004 and 2007 is just one more indication that trends in atmospheric mercury concentrations are changing worldwide.

Trends in mercury concentrations and mercury wet deposition are most likely related to changes in worldwide emission (Pacyna et al., 2016). Most anthropogenic emission inventories show nearly constant or increasing anthropogenic emissions between 1990 and 2010 (Wilson et al., 2010; Streets et al., 2011; Muntean et al., 2014), which is inconsistent with the worldwide decreasing trend in atmospheric mercury concentrations and mercury wet deposition over this period. This inconsistency has been explained by decreasing emissions from the North Atlantic Ocean due to reduced mercury concentrations in subsurface ocean water (Soerensen et al., 2012) and more recently by a substantial reduction of mercury emissions from coal-fired power plants and from commercial products between 1990 and 2000 (Zhang et al., 2016). The most recent inventory by Zhang et al. (2016) estimated that worldwide anthropogenic emissions decreased from $2890 \mathrm{Mg}$ year $^{-1}$ in 1990 to $2160 \mathrm{Mg}$ year $^{-1}$ in 2000 and increased slightly to $2280{\mathrm{Mg} y e a r^{-1}}^{-1}$ in 2010 . To the best of our knowledge no more recent emission estimates have been published so far (the emission estimates are always delayed by several years, needed for the collection of the underlying statistical data). Since the potential to reduce emissions from the commercial products and from coal-fired power plants was largely exhausted between 1990 and 2000, a further increase of worldwide mercury emissions between 
Table 1. Sen's slopes calculated from monthly GEM averages of all and baseline (i.e., ${ }^{222} \mathrm{Rn} \leq 250 \mathrm{mBq} \mathrm{m}^{-3}$ ) data for March $2007-\mathrm{June}$ 2015.

\begin{tabular}{lrrrr}
\hline Data & $\begin{array}{r}\text { Sen's slope } \\
{\left[\mathrm{ng} \mathrm{m}^{-3} \text { year }^{-1}\right]}\end{array}$ & $\begin{array}{r}\text { Significance } \\
{[\%]}\end{array}$ & $\begin{array}{r}\text { Range at 95\% signif. level } \\
{\left[\mathrm{ng} \mathrm{m}^{-3} \text { year }^{-1}\right]}\end{array}$ \\
\hline All data & 0.0210 & 99 & $>99.98$ & $0.0127-0.0284$ \\
All Baseline & 0.0208 & 97 & $>99.98$ & $0.0141-0.0280$ \\
Fall (MAM, all data) & 0.0089 & 27 & 95.99 & $-0.0009-0.0198$ \\
Fall (MAM, baseline) & 0.0108 & 27 & 98.78 & $0.0018-0.0223$ \\
Winter (JJA, all data) & 0.0153 & 25 & 99.29 & $0.0025-0.0294$ \\
Winter (JJA, baseline) & 0.0152 & 25 & 98.68 & $0.0020-0.0287$ \\
Spring (SON, all data) & 0.0375 & 24 & 99.74 & $0.0142-0.0556$ \\
Spring (SON, baseline) & 0.0361 & 24 & 99.84 & $0.0160-0.0563$ \\
Summer (DJF, all data) & 0.0287 & 23 & 99.87 & $0.0119-0.0440$ \\
Summer (DJF, baseline) & 0.0269 & 21 & 99.79 & $0.0020-0.0287$ \\
\hline
\end{tabular}

Table 2. Least-squares fit of monthly median of all GEM concentrations for September 1995-December 2004.

\begin{tabular}{lrrr}
\hline Data & $\begin{array}{r}\text { Slope } \\
{\left[\mathrm{ng} \mathrm{m}^{-3} \text { year }^{-1}\right]}\end{array}$ & $n$ & $\begin{array}{r}\text { Signif. level } \\
{[\%]}\end{array}$ \\
\hline All data & $-0.0176 \pm 0.0027$ & 94 & $>99.9$ \\
Fall (MAM) & $-0.0132 \pm 0.0052$ & 23 & $>95$ \\
Winter (JJA) & $-0.0189 \pm 0.0049$ & 23 & $>99.9$ \\
Spring (SON) & $-0.0198 \pm 0.0038$ & 24 & $>99.9$ \\
Summer (DJF) & $-0.0154 \pm 0.0065$ & 24 & $>95$ \\
\hline
\end{tabular}

2010 and 2015, mostly from increasing coal burning and artisanal small-scale gold mining, can be expected.

Seasonally resolved trends may provide some information about the processes influencing the trends at Cape Point. The trends were calculated for different seasons (austral fall March, April, May; winter - June, July, August; spring September, October, November; and summer - December, January, February) for the period from March 2007 until June 2015 from all and baseline data. These are listed in Table 1. Although the $95 \%$ uncertainty ranges of seasonal Sen's slopes overlap, the least-squares fit slopes for different seasons are statistically different at the $>99 \%$ significance level. Irrespective of whether monthly averages or medians, least-squares fit, or Sen's slope are used, a consistent picture emerges with upward trends where the slopes decrease in the following order: austral spring $(\mathrm{SON})>$ summer $(\mathrm{DJF})>$ winter $(\mathrm{JJA})>$ fall $(\mathrm{MAM})$. Seasonal trends for the 1995-2004 period shown in Table 2 are all downward, and their slopes decrease in the following order: austral fall $>$ summer $>$ winter $>$ spring (note the negative sign of the slopes). The difference between fall and summer as well as between winter and spring is not significant. In absolute terms the slope is smallest during austral autumn (MAM) and highest for spring (SON) for both the 1995-2004 and 2007-2015 data sets.
The difference in seasonal GEM trends could originate from the seasonal trends of GEM emissions. $\mathrm{Hg}$ emissions from coal-fired power plants, the largest anthropogenic $\mathrm{Hg}$ source, tend to be nearly constant over the year (Rotty, 1987). However, biomass burning is a highly seasonal phenomenon with maximum emissions during August-September both in South America and southern Africa (Duncan et al., 2003; van der Werf et al., 2006). Taking into account a delay by $\sim 3$ months due to intra-hemispherical air mixing time, OctoberNovember coincides with the maximum absolute seasonal trends: an upward one for 2007-2015 and a downward one for the 1995-2004 period. Biomass burning emission inventories suggest a small decrease in $\mathrm{CO}$ emissions from Africa and a more pronounced one from South America between 1997 and 2004, but differences between different inventories render it very uncertain (Granier et al., 2011). As the emission estimates by Granier et al. (2011) end in 2010, no trend in emissions from biomass burning in the 2007-2015 period can be given. Nonetheless, the ambient Cape Point CO data have shown a measurable decrease during 2003 till 2014 (Toihir et al., 2015). We tried to calculate seasonal trends of baseline CO mixing ratios for the 1995-2004 and 2007June 2015 periods, but none of the trends was significant. The 1995-2004 and 2007-June 2015 periods are probably too short to reveal trends in $\mathrm{CO}$ data obscured by strong seasonal and interannual variations. Nevertheless, the El NiñoSouthern Oscillation (ENSO) signature both in $\mathrm{Hg}$ and $\mathrm{CO}$ data from Cape Point, Mace Head, and CARIBIC was found to be consistent, within large uncertainty margins, with emissions from biomass burning (Slemr et al., 2016). In summary, seasonal variations of emissions from biomass burning in southern Africa and South America as well as ENSO signature are consistent with a hypothesis of emissions from biomass burning as a major driving force behind the different seasonal trends as seen in the Cape Point data.

Seasonal variation of mercury concentrations was also investigated. For this we detrended the monthly averages using their least-squares fits. The detrended monthly averages 

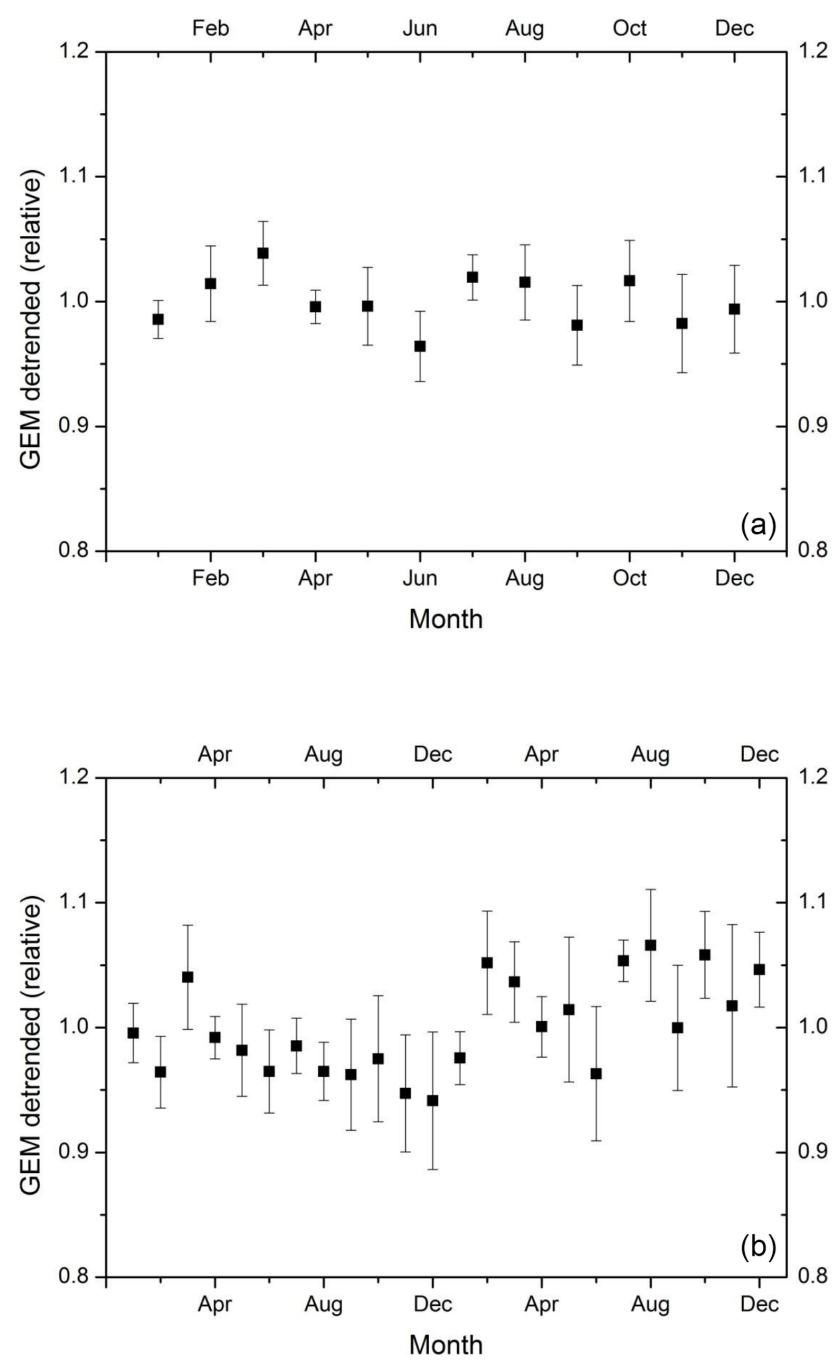

Figure 2. Seasonal (upper panel) and biennial (lower panel) variation of detrended monthly averages. The error bars denote the standard error of the monthly average.

were then averaged according to months. Figure 2a shows the seasonal variation of relative monthly averages with their respective standard error. No systematical seasonal variation is apparent in this plot. We noted, however, a 2-year periodicity in the monthly averages. Figure $2 b$ shows the monthly averages of the detrended monthly values for a 2-year period. Despite the somewhat higher standard errors of the monthly averages (number of averaged months for biennial variation being only half of those for the seasonal variation), the monthly averages vary between 0.95 and 1.05 , as do the monthly averages for the seasonal variation (Fig. 1a). Taken collectively, however, the relative GEM concentrations during the second year are significantly (>99.9\%) higher than those in the first year. This is a clear sign of a biennial variation of GEM concentrations at Cape Point.

Tropospheric biennial oscillations (TBOs) in tropospheric temperature, pressure, wind field, monsoon, etc. has been previously reported in the literature (e.g., Meehl, 1997; Meehl and Arblaster, 2001, 2002; Zheng and Liang, 2005). Meehl and Arblaster (2001) also report that TBOs with roughly a 2-3-year period encompass most ENSO years with their well-known biennial tendency. Slemr et al. (2016) analyzed mercury data from Cape Point in South Africa, Mace Head in Ireland, and CARIBIC measurements in the upper troposphere and found an ENSO signature in all these data sets. Thus the finding of biennial variation of GEM concentrations at Cape Point is consistent with the ENSO influence.

\section{Conclusions}

We report here an upward trend for mercury concentrations at Cape Point for the period 2007-2015. As mercury concentrations at Cape Point decreased over the period 1995-2004, we conclude that the trend must have changed sign between 2004 and 2007. Such a change is qualitatively consistent with the trend changes observed in atmospheric mercury concentrations at Mace Head in the Northern Hemisphere (Weigelt et al., 2015) and in mercury wet deposition at sites in North America (Weiss-Penzias et al., 2016). Combining all this evidence, it seems that the worldwide mercury emissions are now increasing, after a decade or two of decreasing emissions. This finding is consistent with the temporal development of mercury emissions in the most recent mercury inventory (Zhang et al., 2016).

For both periods, 1995-2004 and 2007-2015, seasonally resolved trends were different in different seasons. We believe that the observed trends of GEM concentrations at Cape Point result from the trend of worldwide mercury emissions and are additionally modulated by regional influences. During 1995-2004 the highest downward trend was observed in austral spring (SON) and winter (JJA). For the 2007-2015 period the highest upward trend was found in austral spring. $\mathrm{Hg}$ emissions from biomass burning in South America and southern Africa both peak in August and September (Duncan et al., 2003; van der Werf et al., 2006). Although the trend of these emissions is uncertain because of differences between different emission inventories (Granier et al., 2011), it can produce different trends in different seasons. Biennial variation of the GEM concentrations at Cape Point, reported here, suggest that climatological changes of transport patterns can also play a role in seasonally different trends. The detection of the ENSO signature in GEM concentrations at Cape Point (Slemr et al., 2016) is consistent with the influence of both emissions from biomass burning and changing regional transport patterns.

\section{Data availability}

The data sets are available from the GMOS data portal (http:// sdi.iia.cnr.it/geoint/publicpage/GMOS/gmos_historical.zul). 
Competing interests. The authors declare that they have no conflict of interest.

Acknowledgements. The GEM measurements made at Cape Point have been supported by the South African Weather Service and have also received financial support from the GMOS, a European Community-funded FP7 project (ENV.2010.4.1.3-2). We are grateful to Danie van der Spuy for the general maintenance of the Tekran analyzer at Cape Point.

Edited by: N. Pirrone

Reviewed by: two anonymous referees

\section{References}

Brunke, E.-G., Labuschagne, C., Parker, B., Scheel, H. E., and Whittlestone, S.: Baseline air mass selection at Cape Point, South Africa: Application of ${ }^{222} \mathrm{Rn}$ and other filter criteria to $\mathrm{CO}_{2}$, Atmos. Environ., 38, 5693-5702, 2004.

Brunke, E.-G., Labuschagne, C., Ebinghaus, R., Kock, H. H., and Slemr, F.: Gaseous elemental mercury depletion events observed at Cape Point during 2007-2008, Atmos. Chem. Phys., 10, 11211131, doi:10.5194/acp-10-1121-2010, 2010.

Brunke, E.-G., Ebinghaus, R., Kock, H. H., Labuschagne, C., and Slemr, F.: Emissions of mercury in southern Africa derived from long-term observations at Cape Point, South Africa, Atmos. Chem. Phys., 12, 7465-7474, doi:10.5194/acp-12-74652012, 2012.

Duncan, B. N., Martin, R. V., Staudt, A. C., Yevich, R., and Logan, J. A.: Interannual and seasonal variability of biomass burning emissions constrained by satellite observations, J. Geophys. Res., 108, 4100, doi:10.1029/2002JD002378, 2003.

Ebinghaus, R., Jennings, S. G., Schroeder, W. H., Berg, T., Donaghy, T., Guentzel, J., Kenny, C., Kock, H. H., Kvietkus, K., Landing, W., Mühleck, T., Munthe, J., Prestbo, E. M., Schneeberger, D., Slemr, F., Sommar, J., Urba, A., Wallschläger, D., and Xiao, Z.: International field intercomparison measurements of atmospheric mercury species, Atmos. Environ., 33, 3063-3073, 1999.

Ebinghaus, R., Jennings, S. G., Kock, H. H., Derwent, R. G., Manning, A. J., and Spain, T. G.: Decreasing trend in total gaseous mercury observations in baseline air at Mace Head, Ireland, from 1996 to 2009, Atmos. Environ., 45, 3475-3480, 2011.

Gay, D. A., Schmeltz, D., Prestbo, E., Olson, M., Sharac, T., and Tordon, R.: The Atmospheric Mercury Network: measurement and initial examination of an ongoing atmospheric mercury record across North America, Atmos. Chem. Phys., 13, 1133911349, doi:10.5194/acp-13-11339-2013, 2013.

Granier, C., Bessagnet, B., Bond, T., D’Angiola, A., Denier van der Gon, H., Frost, G. J., Heil, A., Kaiser, J. W., Kinne, S., Klimont, Z., Kloster, S., Lamarque, J.-F., Liousse, C., Masui, T., Meleux, F., Mieville, A., Ohara, T., Raut, J.-C., Riahi, K., Schultz, M. G., Smith, S. J., Thompson, A., van Aardenne, J., van der Werff, G. R., and van Vuuren, D. P.: Evolution of anthropogenic and biomass burning emissions o fair pollutants at global and regional scales during the 1980-2010 period, Clim. Change, 109, 163-190, 2011.
Lindberg, S., Bullock, R., Ebinghaus, R., Engstrom, D., Feng, X., Fitzgerald, W., Pirrone, N., Prestbon, E., and Seigneur, C.: A synthesis of progress and uncertainties in attributing the sources of mercury in deposition, Ambio, 36, 19-32, 2007.

Meehl, G. A.: The South Asian monsoon and the tropospheric biennial oscillation, J. Climate, 10, 1921-1943, 1997.

Meehl, G. A. and Arblaster, J. M.: The tropospheric biennial oscillation and Indian monsoon rainfall, Geophys. Res. Lett., 28, 1731-1734, 2001.

Meehl, G. A. and Arblaster, J. M.: The tropospheric biennial oscillation and Asian-Australian monsoon rainfall, J. Climate, 15, 722-744, 2002.

Mergler, D., Anderson, H. A., Chan, L. H. N., Mahaffey, K. R., Murray, M., Sakamoto, M., and Stern, A. H.: Methylmercury exposure and health effects in humans: A worldwide concern, Ambio, 36, 3-11, 2007.

Muntean, M., Janssens-Maenhout, G., Song, S., Selin, N. E., Olivier, J. G. J., Guizzardi, D., Maas, R., and Dentener, F.: Trend analysis from 1970 to 2008 and model evaluation of EDGARv4 global gridded anthropogenic mercury emissions, Sci. Total Environ., 494-495, 337-350, 2014.

Pacyna, J. M., Travnikov, O., De Simone, F., Hedgecock, I. M., Sundseth, K., Pacyna, E. G., Steenhuisen, F., Pirrone, N., Munthe, J., and Kindbom, K.: Current and future levels of mercury atmospheric pollution on a global scale, Atmos. Chem. Phys., 16, 12495-12511, doi:10.5194/acp-16-12495-2016, 2016.

Prestbo, E. M. and Gay, D. A.: Wet deposition of mercury in the U.S. and Canada, 1996-2005: Results and analysis of the NADP mercury deposition network (MDN), Atmos. Environ., 43, 42234233, 2009.

Rotty, R. M.: Estimates of seasonal variation in fossil fuel $\mathrm{CO}_{2}$ emission, Tellus B, 39, 184-202, 1987.

Salmi, T., Määttä, A., Anttila, P., Ruoho-Airola, T., and Amnell, T.: Detecting trends of annual values of atmospheric pollutants by the Mann-Kendall test and Sen's slope estimates - the Excel template application Makesens, Finnish Meteorological Institute, Helsinki, Finland, 2002.

Scheuhammer, A. M., Meyer, M. W., Sandheinrich, M. B., and Murray, M. W.: Effects of environmental methylmercury on the health of wild birds, mammals, and fish, Ambio, 36, 12-18, 2007.

Selin, N. E.: Global biogeochemical cycling of mercury: A review, Ann. Rev. Environ. Resour., 34, 43-63, doi:10.1146/annurev.environ.051308.084314, 2009.

Selin, N. E., Jacob, D. J., Yantoska, R. M., Strode, S., Jaeglé, L., and Sunderland, E. M.: Global 3-D land-ocean-atmosphere model for mercury: Present-day versus preindustrial cycles and anthropogenic enrichment factors for deposition, Global Biogeochem. Cy., 22, GB2011, doi:10.1029/2007GB003040, 2008.

Slemr, F., Brunke, E.-G., Labuschagne, C., and Ebinghaus, R.: Total gaseous mercury concentrations at the Cape Point GAW station and their seasonality, Geophys. Res. Lett., 35, L11807, doi:10.1029/2008GL033741, 2008.

Slemr, F., Brenninkmeijer, C. A. M., Rauthe-Schöch, A., Weigelt, A., Ebinghaus, R., Brunke, E.-G., Martin, L., Spain, T. G., and O'Doherty, S.: El Niño - Southern Oscillation influence on tropospheric mercury concentrations, Geophys. Res. Lett., 43, 1766-1771, 2016.

Soerensen, A. L., Jacob, D. J., Streets, D. G., Witt, M. L. I., Ebinghaus, R., Mason, R. P., Andersson, M., and Sun- 
derland, E. M.: Multi-decadal decline of mercury in the North-Atlantic atmosphere explained by changing subsurface seawater concentrations, Geophys. Res. Lett., 39, L21810, doi:10.1029/2012GL053736, 2012.

Sprovieri, F., Pirrone, N., Ebinghaus, R., Kock, H., and Dommergue, A.: A review of worldwide atmospheric mercury measurements, Atmos. Chem. Phys., 10, 8245-8265, doi:10.5194/acp10-8245-2010, 2010.

Sprovieri, F., Pirrone, N., Bencardino, M., D’Amore, F., Carbone, F., Cinnirella, S., Mannarino, V., Landis, M., Ebinghaus, R., Weigelt, A., Brunke, E.-G., Labuschagne, C., Martin, L., Munthe, J., Wängberg, I., Artaxo, P., Morais, F., Barbosa, H. D. M. J., Brito, J., Cairns, W., Barbante, C., Diéguez, M. D. C., Garcia, P. E., Dommergue, A., Angot, H., Magand, O., Skov, H., Horvat, M., Kotnik, J., Read, K. A., Neves, L. M., Gawlik, B. M., Sena, F., Mashyanov, N., Obolkin, V., Wip, D., Feng, X. B., Zhang, H., Fu, X., Ramachandran, R., Cossa, D., Knoery, J., Marusczak, N., Nerentorp, M., and Norstrom, C.: Atmospheric mercury concentrations observed at ground-based monitoring sites globally distributed in the framework of the GMOS network, Atmos. Chem. Phys., 16, 11915-11935, doi:10.5194/acp16-11915-2016, 2016.

Streets, D. G., Devane, M. K., Lu, Z., Bond, T. C., Sunderland, E. M., and Jacob, D. J.: All-time releases of mercury to the atmosphere from human activities, Environ. Sci. Technol., 45, 1048510491, 2011.

Temme, C., Planchard, P., Steffen, A., Banic, C., Beauchamp, S., Poissant, L., Tordon, R., and Wiens, B.: Trend, seasonal and multivariate analysis study of total gaseous mercury data from the Canadian Atmospheric Mercury Measurement Network (CAMNet), Atmos. Environ., 41, 5423-5441, 2007.
Toihir, A. M., Venkataraman, S., Mbatha, N., Sangeetha, S. K., Bencherif, H., Brunke, E.-G., and Labuschagne, C.: Studies on $\mathrm{CO}$ variation and trends over South Africa AUTHORS: and the Indian ocean using TES satellite data, S. Afr. J. Sci., Volume 111, Number 9/10 Sep/Oct 2015, http://www.sajs.co.za, 2015.

van der Werf, G. R., Randerson, J. T., Giglio, L., Collatz, G. J., Kasibhatla, P. S., and Arellano Jr., A. F.: Interannual variability in global biomass burning emissions from 1997 to 2004, Atmos. Chem. Phys., 6, 3423-3441, doi:10.5194/acp-6-3423-2006, 2006.

Weigelt, A., Ebinghaus, R., Manning, A. J., Derwent, R. G., Simmonds, P. G., Spain, T. G., Jennings, S. G., and Slemr, F.: Analysis and interpretation of 18 years of mercury observations since 1996 at Mace Head at the Atlantic Ocean coast of Ireland, Atmos. Environ., 100, 85-93, 2015.

Weiss-Penzias, P. S., Gay, D. A., Brigham, M. E., Parsons, M. T., Gustin, M. S., and ter Schure, A.: Trends in mercury wet deposition and mercury air concentrations across the U.S. and Canada, Sci. Total Environ., 568, 546-556, 2016.

Wilson, S., Munthe, J., Sundseth, K., Kindbom, K., Maxson, P., Pacyna, J., ans Steenhuisen, F.: Updating historical global inventories of anthropogenic mercury emissions to air, AMAP Technical Report No. 3, 14 pp., Arct. Monit. And Assess. Programme, Oslo, 2010.

Zhang, Y., Jacob, D. J., Horowitz, H. M., Chen, L., Amos, H. M., Krabbenhoft, D. P., Slemr, F., Louis, V. L. St., and Sunderland, E. M.: Observed decrease in atmospheric mercury explained by global decline in anthropogenic emissions, P. Natl. Acad. Sci. USA, 113, 526-531, 2016.

Zheng, B. and Liang, J.-Y.: Advance in studies of tropospheric biennial oscillation, J. Tropical Meteorol., 11, 1-9, 2005. 